\title{
Faktor-Faktor Teknis dan Keorganisasian yang Memengaruhi Pengembangan Sistem Pengukuran Kinerja Pemerintah Daerah
}

\author{
Warka Syachbrani \\ Rusdi Akbar \\ Fakultas Ekonomika dan Bisnis Universitas Gadjah Mada \\ Email: warka.syachbrani@mail.ugm.ac.id
}

\begin{abstract}
This study aims to empirically examine the influence of technical and organizational factors to the development of public performance measurement system in Indonesia local government. A total of 50 respondents used in this study were the auditors and officials of the Kantor Inspektorat of Kabupaten Sleman, Daerah Istimewa Yogyakarta. Analysis of Partial Least Square (PLS) is used in testing the hypotheses of this research. The results of this study demonstrate the metrics difficulty of performance indicators and educational background significantly influence the development of public performance measurement system for the incentives orientation of the local government. Meanwhile, employee training and organizational culture factors significantly influence the development of public performance measurement system for the exploration orientation.
\end{abstract}

Keywords: Institutional Theory, Isomorphism, PLS Analysis, Public Performance Measurement System

\section{PENDAHULUAN}

Pada dekade 1980-an, beberapa negara di daratan Eropa dan Amerika melakukan transformasi dengan melakukan adopsi sistem manajemen sektor privat untuk diterapkan pada sistem pengelolaan negara mereka. Gagasan tersebut kemudian melahirkan konsep pengelolaan sektor publik yang dikenal dengan konsep New Public Management (NPM) (Hood, 1991). NPM kemudian membawa angin segar bagi tata kelola pemerintahan dengan salah satu prinsip yang diusung adalah transparansi dan akuntabilitas kinerja personel entitas sektor pubik.

Di Indonesia, dengan bergulirnya reformasi pada tahun 1998 kemudian menjadi cikal-bakal sistem pengelolaan Negara yang lebih transparan dan akuntabel. Keadaan tersebut menyebabkan disahkan Instruksi Presiden nomor 7 Tahun 1999 tentang Laporan Akuntabilitas Kinerja Institusi Pemerintah atau dikenal dengan akronim LAKIP. Secara teknis, aturan tentang pelaporan pengukuran kinerja lembaga pemerintah di semua tingkat tertuang dalam Keputusan Kepala Lembaga Administrasi Negara (LAN) nomor 589/IX/6/Y/1999 tentang Pedoman Penyusunan Pelaporan Akuntabilitas Kinerja Instansi Pemerintah kemudian direvisi dengan Keputusan Kepala LAN Nomor 239/IX/6/8/2003. Hal tersebutlah yang menjadi fokus kajian dari penelitian ini.

Sistem Pengukuran Kinerja (SPK) sangat penting untuk menjadi perhatian utama karena SPK terbukti banyak berkontribusi dalam upaya peningkatan kualitas kinerja institusi pemerintah. Menurut Spékle dan Verbeeten (2009) bahwa SPK merupakan kunci utama dalam mewujudkan manajemen sektor publik yang efektif, efisien, dan akuntabel. Namun, pada kenyataan praktiknya SPK di Indonesia masih belum berperan dalam meningkatkan akuntabilitas kinerja institusi pemerintah. Nurkhamid (2008) menemukan bahwa kemampuan SPK untuk mewujudkan transparansi dan akuntabilitas kinerja Pemerintah masih dipertanyakan, hal tersebut disinyalir karena implementasi dan pengembangan SPK masih sebatas

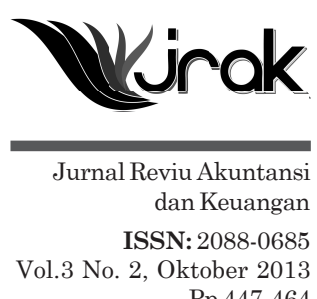


Faktor-Faktor Teknis dan Keorganisasian... paksaan atas regulasi yang ada (Silaloho dan Halim, 2005). Lebih jauh, Akbar et al. (2012) menemukan bahwa pengembangan SPK di Pemerintahan Daerah di Indonesia dalam hal penggunaan hasil dan implementasi masih sangat terbatas dan hanya sekedar formalitas saja.

Ketidaksuksesan penerapan sistem baru pada manajemen pemerintahan di Indonesia disebabkan karena banyak hambatan. Beberapa literatur yang telah melakukan studi terhadap penerapan sistem manajemen baru di negara-negara sedang berkembang. De Bruijn (2002) menemukan bahwa para pimpinan dan manajer di sektor publik di negara-negara berkembang mengkhawatirkan sistem baru akan mengganggu kebijakan-kebijakan yang sebelumnya telah ada. Selain itu, institusi publik juga terkendala dalam hal kesiapan sumber daya untuk mendukung pelaksanaan sistem baru tersebut (Spékle dan Verbeeten, 2009). Berdasarkan hal tersebut, peneliti bermaksud akan mengkaji bagaimana SPK di Indonesia dikembangkan sehingga dapat diimplementasikan dengan baik dan berfungsi sebagai mana mestinya.

Penelitian SPK di sektor publik pada dekade terakhir sebenarnya tampak semakin marak dilakukan. Penelitian-penelitian tersebut banyak melakukan pengkajian pada Pemerintah Daerah pada pejabat Satuan Kerja Perangkat Daerah yang hanya menjalankan regulasi pemerintahan (mis: Silaloho dan Halim, 2005; Nurkhamid, 2008; Akbar at al, 2012; Wijaya dan Akbar, 2013). Sebagai kebaruan dalam studi ini, maka peniliti berinisiatif untuk melakukan penelitian tentang bagaimana para personel atau pejabat yang bertugas dalam bidang standarisasi dan pemeriksaan terhadap pelaksanaan kinerja perangkat pemerintah daerah dalam mengembangkan SPK untuk mengukur dan mengevaluasi kinerja di pemerintahan daerah. Penelitian ini dilaksanakan di Kantor Inspektorat Pemerintah Kabupaten Sleman, Provinsi DI. Yogyakarta.

Peneliti menguji faktor-faktor teknis dan keorganisasian sebagai faktor yang memengaruhi pengembangan SPK berdasarkan beberapa literatur terdahulu yang telah melakukan studi pada bidang yang sama. Faktor-faktor teknis yang terdiri dari kesulitan dalam menentukan indikator kinerja (Cavaluzzo dan Ittner, 2004; Akbar et al., 2012), latar belakang pendidikan (Chin et al., 2010), dan pelatihan pegawai (Parlinda, 2003; Nurkhamid, 2008) yang masing-masing telah terbukti memengaruhi pengembangan dan implementasi SPK. Sedangkan faktor-faktor keorganisasian seperti: budaya organisasi (Schein,1992; Julnes dan Holzer, 2001; Nurkhamid, 2008), serta Kesamaran Tujuan dan Sasaran Organisasi (Julnes \& Holzer, 2001, Wang, 2002; Sihaloho dan Halim, 2005) juga telah terbukti memengaruhi pengembangan SPK.

Setelah penjelasan mengenai latar belakang yang mendasari penelitian ini dilakukan, peneliti memaparkan dasar teori dan pengembangan hipotesis pada bagian selanjutnya. Kemudian penjelasan mengenai metodologi penelitian akan dijelaskan berikutnya yang disusul dengan pemaparan hasil temuan, kesimpulan serta keterbatasan dari penelitian ini.

\section{Teori dan Pengembangan Hipotesis}

\section{Teori Institusional dan Isomorphisma}

Permulaan abad 20 merupakan masa tumbuh dan berkembangnya Teori Institusional (the institutional theory) sebagai kerangka teori yang menjelaskan fenomena sosial dengan dasar perubahan pada sebuah institusi. Gagasan utama dari teori tersebut adalah bahwa organisasi dibentuk oleh lingkungan institusional yang mengitarinya dan dengan begitu pengkajian pada sebuah organisasi haruslah dipandang sebagai sebuah totalitas simbol, bahasa, ataupun ritual-ritual yang melingkupinya (Gudono, 2014). Konsep institusional menjelaskan bahwa organisasi dipengaruhi oleh tekanan normatif yang kadang timbul dari lingkungan eksternal maupun dari dalam organisasi itu sendiri. 
Dalam berbagai kondisi, tekanan eksternal mengarahkan organisasi pada unsur yang dilegitimasi seperti regulasi atau standard operasi. DiMaggio dan Powell (1983) berteori bahwa organisasi dibentuk oleh kekuatan-kekuatan dari luar organisasi tersebut melalui proses ketaatan (compliance), peniruan, dan proses kognisi. Lebih lanjut, bahwa struktur dan proses organisasi cenderung menjadi isomorpis dengan norma-norma yang dapat mereka terima untuk dilaksanakan. Hal tersebut menyebabkan individu-individu dalam organisasi hanya mengandalkan pengalaman mereka untuk meminimalkan masalah dalam rangka mengahadapi masalah-masalah baru, sekaligus sebagai usaha untuk bertanggung jawab bagi pihak eksternal.

DiMaggio dan Powell lebih lanjut menjelaskan bahwa isomorphisma sebagai constraining process yang memaksa satu unit di dalam populasi untuk memiliki wujud atau sifat yang sama dengan unit yang lain yang menghadapi kondisi lingkungan yang sama. Dalam proses tersebut disebutkan terdapat tiga mekanisme terjadinya isomorphisma institusional; mekanisme coercive isomorphism, mekanisme mimetic isomorphism, dan mekanisme normative isomophism.

Isomorphisma dengan mekanisme coercive merupakan hasil dari tekanan formal maupun informal yang diberikan pada organisasi dengan organisasi lainnya dimana mereka saling bergantung dan dengan ekspektasi budaya dalam masyarakat yang didalamnya terdapat fungsi organisasi. Selanjutnya isomorphisma dengan proses mimetic, yakni organisasi mungkin menjadikan diri mereka sebagai model yang sama seperti organisasi lain dan juga menjadi alasan yang kuat untuk mendorong melakukan imitasi ketika teknologi organisasi kurang dipahami (March dan Olsen, 1976 dalam DiMaggio dan Powell, 1983), ketika tujuan organisasi menjadi ambigu, atau ketika terjadi ketidakpastian lingkungan organisasi. Terakhir, isomorphisma dengan tekanan normative dimana komitmen terhadap organisasi dan kesetiaan profesionalisme sebagai perjuangan secara kolektif dari anggota organisasi untuk menentukan kondisi dan metoda kerja mereka untuk mengontrol kinerja dan sebagai basis kognitif mereka untuk melegitimasi otonomi pekerjaan mereka. Hal tersebut dapat bersumber dari pendidikan formal dan legitimasi dalam basis kognitif yang dihasilkan oleh pakar perguruan tinggi, yang kedua adalah pertumbuhan dan perluasan jaringan profesional yang mencakup organisasi dan dimana model-model baru menyebar dengan cepat.

Berkaitan dengan pengembangan dan implementasi sistem pengukuran kinerja di pemerintah Indonesia, Akbar et al., (2012) menemukan bahwa mekanisme isomorphisma yang terjadi di Pemerintah Daerah adalah mekanisme coercive dan normative. Studi tersebut menemukan bahwa aparat pemerintah daerah dalam mengembangkan sistem pengukuran kinerja hanya bersifat conformance bukan performance. Pemerintah daerah cenderung hanya melakukannya karena alasan keharusan dari pemerintah pusat. Di sisi lain, secara normative para manajer di pemerintah daerah telah mengembangkan sistem pengukuran kinerja karena adanya tambahan pengetahuan teknis mereka melalui pelatihan-pelatihan pegawai.

\section{Pengembangan Sistem Pengukuran Kinerja Pemerintah}

Menurut Nurkhamid (2008), suatu ukuran kinerja yang tepat akan dapat membantu organisasi mengetahui seberapa baik suatu program yang dijalankan, pencapaian tujuan suatu kegiatan, tingkat kepuasan pelanggan, pengendalian secara statistik suatu proses kegiatan, serta pengembangan yang diperlukan diperlukan atas suatu kegiatan. Mardiasmo (2009) menuliskan bahwa tujuan sistem pengukuran kinerja adalah; (1) untuk mengkomunikasikan strategi secara lebih baik (top down dan bottom up), (2) untuk mengukur kinerja finansial dan nonfinansial secara berimbang sehingga dapat ditelusur perkembangan pencapaian strategi, (3) untuk mengakomodasi pemahaman kepentingan manager level menengah dan bawah serta memotivasi untuk mencapai goal congruence, dan (4) sebagai alat untuk mencapai kepuasan berdasarkan pendekatan individual dan kemampuan kolektif yang rasional. 
Faktor-Faktor

Teknis dan

Keorganisasian...
Speklé dan Verbeeten (2009) menjelaskan tujuan pengembangan dan implementasi sistem pengukuran kinerja pada praktik sektor publik dengan menghubungkan tiga peran organisasi yang berbeda dari sistem pengukuran kinerja: (1) sistem yang dapat diterapkan untuk tujuan operasional, yaitu didalamnya termasuk perencanaan sampai proses pemantauan; (2) sistem yang dapat digunakan untuk penyediaan insentif dan penghargaan, dan (3) sistem yang dapat digunakan dengan cara eksplorasi, yaitu untuk double-loop learning, penentuan prioritas dan pengembangan kebijakan, karena melakukan eksplorasi terhadap kapabilitas strategis merupakan core atau backbone dari keberhasilan reformasi birokrasi yang menurut Panozzo (2000) bahwa organisasi publik di negara-negara berkembang memperlihatkan adanya komitmen pemerintahan untuk melakukan reformasi organisasi pada sektor publik.

Penelitian ini kemudian mencoba berfokus untuk menganalisa secara khusus tujuan pengembangan sistem pengukuran dan evaluasi kinerja anggaran lembaga pemerintah dari aspek tujuan operasional, aspek tujuan penyediaan insentif atau penghargaan, dan aspek tujuan pengembangan atau eksplorasi. Hal tersebut dimungkinkan dengan berdasarkan Speklé dan Verbeeten (2009) yang menjelaskan bahwa tiga peran dari sistem pengukuran kinerja yang dibedakan tersebut adalah tidak bersifat mutually exclusive, artinya, penggunaan salah satu peran dari sistem tersebut tidak berarti menolak penggunaan peran yang lain (Mardiasmo, 2009), dengan demikian dapat menggunakan peran yang berbeda, dan bisa juga dipakai secara bersama-sama. Penelitian ini juga senada dengan penelitian pada bidang yang sama oleh Wijaya dan Akbar (2013) yang telah menguji penggunaan sistem pengukuran kinerja pada pemerintah daerah di Indonesia dengan menggunakan 3 bentuk tujuan sistem pengukuran tersebut digunakan dan dikembangkan.

\section{Faktor-faktor Teknis dan Pengembangan SPK Pemerintah}

\section{Kesulitan Menentukan Indikator Kinerja}

Kesulitan menentukan ukuran kinerja (metrics difficulty) yang dimaksudkan dalam penelitian ini adalah kesulitan menentukan indikator untuk mengukur kinerja. Menurut Cavalluzzo dan Ittner (2004) bahwa salah satu faktor teknikal dalam literatur sistem pengukuran dan evaluasi kinerja adalah kemampuan dalam mendefinisikan dan mengukur metrik kinerja yang dapat mengukur kinerja dan hasilnya. Hal tersebut menggambarkan bahwa pada praktiknya, pegawai maupun manajer di sektor publik dihadapkan dengan pekerjaan atau tugas yang ternyata sulit untuk diukur dan dievaluasi dengan metrik kuantitatif. Nasir (2010) mengungkapkan bahwa meskipun pengukuran kinerja dengan sistem penganggaran sangat baik dalam meningkatkan kinerja, tetapi yang menjadi kelemahannya adalah tidak mudah mengukur kinerja dalam bentuk outcome.

Kesulitan dalam menentukan ukuran kinerja dapat mengakibatkan ketidaksempurnaan sistem pengukuran dan evaluasi kinerja yang dikembangkan oleh organisasi, sehingga sistem tersebut tidak menjadi informatif. Oleh karena itu, kesulitan dalam menentukan ukuran kinerja tersebut akan mengakibatkan keterbatasan sistem pengukuran dan evaluasi kinerja tersebut untuk digunakan sebagai bahan pertimbangan pengambilan keputusan sehingga berdampak pula pada akuntabilitas (Nurkhamid, 2008).

Penelitian terdahulu telah membuktukan bahwa kesulitan menentukan ukuran kinerja berpengaruh negatif terhadap pengembangan sistem pengukuran kinerja, akuntabilitas kinerja dan penggunaan informasi kinerja yang dihasilkan oleh implementasi sistem pengukuran kinerja (misalnya Cavalluzzo dan Ittner, 2004; Akbar et al., 2012). Hal tersebut mengarahkan hipotesis penelitian ini sebagai berikut;

H1a: Kesulitan menentukan ukuran kinerja berpengaruh negatif terhadap pengembangan sistem pengukuran dan evaluasi kinerja anggaran untuk tujuan operasional. 
H1b: Kesulitan menentukan ukuran kinerja berpengaruh negatif terhadap pengembangan sistem pengukuran dan evaluasi kinerja anggaran untuk tujuan insentif.

H1c: Kesulitan menentukan ukuran kinerja berpengaruh negatif terhadap pengembangan sistem pengukuran dan evaluasi kinerja anggaran untuk tujuan eksplorasi.

\section{Latar Belakang Pendidikan}

Sebuah hasil survei yang dipublikasikan oleh Badan Pemeriksa Keuangan (BPK) Republik Indonesia pada tahun 2009 mengungkapkan bahwa aparat pemerintahan di Indonesia yang bertugas dalam mengelola keuangan Negara masih menunjukkan ketidaksinkronan tugas dan latar belakang pendidikan mereka (Fontanella, 2012). Hal tersebut ikut memengaruhi bagaimana sistem pengukuran kinerja disusun dan dikembangkan karena tugas menetapkan ukuran ataupun indikator kinerja membutuhkan sumber daya manusia dengan latar belakang pendidikan yang sesuai dan memadai. Nasir (2010) mengungkapkan bahwa merumuskan tolok ukur output dan outcome secara tepat dan baik membutuhkan kompetensi sumber daya manusia yang tepat.

Hambrick dan Mason (1984) menemukan bahwa latar belakang pendidikan pegawai memberikan indikasi atas dasar pengetahuan dan keterampilan mereka. Lebih lanjut dikemukakan bahwa bukan hanya berkaitan dengan jumlah atau tingkatan pendidikan yang dimiliki tetapi juga berkaitan dengan relevansi pendidikan tersebut dengan tugas kinerja yang emban seorang pegawai. Hitt dan Tyler (1991) juga membuktikan bahwa seorang pegawai eksekutif yang memiliki pendidikan formal yang sesuai dengan tugasnya memiliki perbedaan kemampuan dan mental dalam membangun model pemecahan masalah dibandingkan dengan pegawai lain yang memiliki latar belakang pendidikan formal yang berbeda.

Seperti yang telah dideskripsikan dalam kumpulan artikel simposium The Urban Institute (2002) dinyatakan bahwa pengembangan dan implementasi sistem pengukuran kinerja harus didukung oleh kepemimpinan dan tim pegawai yang memadai untuk menjamin komitmen organisasi dalam rangka memastikan proses manajemen sistem pengukuran kinerja berada pada tempat dan fungsi yang semestinya. Salah satu unsur yang menggambarkan kualitas dari pimpinan dan pegawai suatu organisasi adalah dukungan latar belakang pendidikannya yang sesuai dengan tugas dan pekerjaaan yang diembannya.

Sebelumnya, Chen et al. (2010) membuktikan bahwa latar belakang pendidikan yang relevan dengan tugas dan tanggung jawab bawahan dalam suatu organisasi akan menyebabkan kepuasan kerja karena dapat memecahkan masalah yang dihadapi dengan mudah sesuai referensi kognisi mereka. Akbar et al. (2012) telah menemukan bahwa pengetahuan teknis berpengaruh secara positif terhadap proses pengembangan dan implementasi sistem pengukuran kinerja pemerintah di Indonesia. Temuan tersebut sedikit banyak telah mendorong peneliti untuk menggagas hipotesis berikutnya untuk diuji secara empiris yang berkaitan dengan dukungan pengetahuan secara teknis yang telah pegawai pemerintah telah dapatkan dari latar belakang pendidikan mereka.

H2a: Latar belakang pendidikan berpengaruh positif terhadap pengembangan sistem pengukuran dan evaluasi kinerja anggaran untuk tujuan operasional.

H2 b: Latar belakang pendidikan berpengaruh positif terhadap pengembangan sistem pengukuran dan evaluasi kinerja anggaran untuk tujuan insentif.

H2c: Latar belakang pendidikan berpengaruh positif terhadap pengembangan sistem pengukuran dan evaluasi kinerja anggaran untuk tujuan eksplorasi.

\section{Pelatihan Pegawai}

Pelatihan terhadap sumber daya manusia (pegawai) yang dimiliki suatu organisasi merupakan suatu usaha untuk memperbaiki dan meningkatkan kinerja 
Faktor-Faktor Teknis dan Keorganisasian... pegawai pada suatu pekerjaan tertentu yang sedang menjadi tanggungjawabnya (Parlinda dan Wahyuddin, 2003). Pemanfaatan ilmu pengetahuan di dalam instansi pemerintah sangat dibutuhkan untuk memberikan pelayanan publik yang lebih baik kepada masyarakat karena setiap bagian dari rangkaian kerja dalam instansi pemerintah harus dilaksanakan dengan terampil oleh personil dalam organisasi tersebut. Dimana personil organisasi tersebut merupakan salah satu unsur yang berfungsi sebagai penggerak jalannya roda organisasi sehingga personil organisasi memiliki peranan yang penting dalam memenuhi tuntutan masyarakat atas pelayanan publik yang lebih baik.

Dalam upaya untuk mendapatkan hasil yang lebih baik maka para personil tersebut harus dibekali dengan pengetahuan dan keterampilan yang cukup. Dengan pengetahuan dan keterampilan yang diberikan maka dapat menunjang organisasi sektor publik untuk mencapai sasaran yang ingin dicapai. Berbagai usaha telah dan/atau sedang dilakukan oleh pemimpin di instansi pemerintah. Mereka menyadari bahwa berhasil atau tidaknya tujuan organisasi tersebut bergantung pada personil yang berada didalamnya.

Dengan demikian pemimpin dalam instansi pemerintah memberikan pelatihan kepada personil dalam instansi tersebut untuk meningkatkan kinerjanya. The Urban Institute (2002) mengungkapkan bahwa personil organisasi yang memiliki pemahaman dan kemampuan teknis yang berkaitan dengan implementasi sistem pengukuran kinerja akan dapat membantu menyukseskan implementasi sistem pengukuran kinerja tersebut. Adapun kemampuan teknis yang diperlukan oleh personil organisasi antara lain untuk melakukan analisis data, menyajikan laporan dalam bentuk yang mudah dipahami, dan membuat laporan khusus yang sesuai dengan karakteristik stakeholder.

Menurut Nurkhamid (2008) berpendapat bahwa pelatihan dapat menciptakan mekanisme bagi para pegawai untuk memahami, menerima, dan merasakan secara nyaman terhadap inovasi, dan mengurangi perasaan tertekan atau kebingungan kepada para pegawai akibat proses implementasi. Misalnya pada pelatihan dalam menentukan target kinerja suatu program, mengembangkan indikator kinerja suatu program, menggunakan informasi kinerja program untuk membuat keputusan, menghubungkan kinerja suatu program dengan pencapaian tujuan strategis instansi tersebut.

Selain itu, pelatihan yang diberikan kepada personil juga dapat meningkatkan komunikasi antara divisi dan departemen tentang pelayanan publik, kinerja, serta pengukuran kinerja (Nurkhamid, 2008). Dimana jumlah personil yang tergabung dalam divisi-divisi tersebut memiliki pengaruh terhadap terwujudnya akuntabilitas kinerja dan penggunaan informasi kinerja jika mereka mampu untuk memahami proses pengukuran kinerja secara kuantitatif maupun kualitatif.

Cavalluzzo dan Ittner (2004), serta Nurkhamid (2008) telah membuktikan bahwa pelatihan yang diberikan kepada pihak manajemen berpengaruh positif terhadap pengembangan sistem pengukuran, akuntabilitas, dan penggunaan informasi kinerja yang dihasilkan oleh implementasi sistem pengukuran kinerja. Berdasarkan uraian tersebut, hipotesis yang diajukan adalah:

H3a: Pelatihan pegawai berpengaruh positif terhadap pengembangan sistem pengukuran dan evaluasi kinerja anggaran untuk tujuan operasional.

H3b: Pelatihan pegawai berpengaruh positif terhadap pengembangan sistem pengukuran dan evaluasi kinerja anggaran untuk tujuan insentif.

H3c: Pelatihan pegawai berpengaruh positif terhadap pengembangan sistem pengukuran dan evaluasi kinerja anggaran untuk tujuan eksplorasi.

\section{Faktor-faktor Keorganisasian dan Pengembangan SPK Pemerintah}

\section{Budaya Organisasi}

Budaya organisasi (organizational culture) merupakan suatu sistem makna bersama yang dianut oleh anggota-anggota yang membedakan organisasi tersebut 
dengan organisasi yang lain. Budaya organisasi memiliki peran penting bagi sebuah organisasi dimana dapat digunakan sebagai pemberi identitas bagi anggota organisasi, menumbuhkan komitmen kolektif, meningkatkan stabilitas sistem sosial, dan membentuk prilaku.

Schein (1992) dalam Julnes dan Holzer (2001) menyatakan bahwa budaya organisasi merupakan suatu pola dari asumsi-asumsi dasar yang ditemukan, diciptakan atau dikembangkan oleh suatu kelompok tertentu dengan maksud agar organisasi belajar mengatasi atau menanggulangi masalah-masalah yang timbul akibat adaptasi eksternal dan integrasi internal yang sudah berjalan dengan cukup baik, sehingga perlu diajarkan kepada anggota-anggota baru sebagaimana cara yang benar untuk memahami, memikirkan, dan merasakan berbagai masalah tersebut.

Berkaitan dengan pengembangan dan implementasi pengukuran kinerja, Julnes dan Holzer (2001) telah membuktikan bahwa budaya organisasi berpengaruh terhadap implementasi sistem pengukuran kinerja. Dalam penelitian ini, budaya organisasi direfleksikan dengan sikap keterbukaan organisasi terhadap perubahan dan inovasi (untuk mengembangkan sistem pengukuran kinerja). Dimana orang-orang yang tergabung dalam organisasi tersebut dapat mengeksplorasi potensi organisasi untuk mencapai hasil yang diinginkan dengan melihat seberapa terbukanya mereka menerima perubahan.

Budaya organisasi berguna untuk memberikan identitas bagi anggota organisasi, menumbuhkan komitmen kolektif, meningkatkan stabilitas sistem sosial, dan membentuk perilaku dengan membantu anggota merasakan kondisi di lingkungan sekitarnya (Kreitner dan Kinicki, 2001) dikutip dalam (Nurkhamid, 2008). Budaya organisasi direfleksikan sebagai sikap keterbukaan organisasi terhadap perubahan inovasi (yaitu sistem pengukuran kinerja). Sihaloho dan Halim (2005) telah membuktikan bahwa budaya organisasi berpengaruh terhadap pengembangan dan implementasi sistem pengukuran kinerja. Berdasarkan uraian tersebut, menghasilkan hipotesis sebagai berikut:

H4a: Budaya organisasi berpengaruh positif terhadap Pengembangan sistem pengukuran dan evaluasi kinerja anggaran untuk tujuan operasional.

H4b: Budaya organisasi berpengaruh positif terhadap Pengembangan sistem pengukuran dan evaluasi kinerja anggaran untuk tujuan insentif.

H4c: Budaya organisasi berpengaruh positif terhadap Pengembangan sistem pengukuran dan evaluasi kinerja anggaran untuk tujuan eksplorasi.

\section{Kesamaran Tujuan dan Sasaran Organisasi}

Orientasi tujuan (goal) organisasi menurut Sihaloho dan Halim (2005) yaitu konsensus terhadap tujuan dari setiap program, kesepakatan atas tujuan dari setiap program dan kegiatan yang akan dilaksanakan membawa pada tujuan kinerja (performance goal), sehingga orientasi tujuan ini memungkinkan organisasi untuk mengadopsi suatu ukuran kinerja, karena menurut Julnes dan dan Holzer (2001) tujuan untuk program biasanya selalu samar-samar dan jika orientasi tujuan hanya merupakan simbolis, maka faktor tersebut memiliki pengaruh lebih besar pada tahap adopsi pengukuran kinerja dibandingkan pada tahap implementasi sistem pengukuran kinerja. Selanjutnya, Wang (2002) menemukan bahwa performance goal berdampak pada proses perencanaan strategik dan proses managemen dan proses evaluasi kinerja karyawan.

Pada kenyataan praktiknya di organisasi sektor publik, penentuan tujuan dan sasaran program seringkali tidak jelas karena banyaknya silang kepentingan dan permainan politik oleh penyelenggara negara. Hal tersebut didukung oleh Wholey (1999) dan De Bruijn (2002) yang mengungkapkan bahwa kesepakatan dalam misi, tujuan dan strategi organisasi harus dicapai dengan melibatkan stakeholders yang beragam, dan para stakeholders tersebut memiliki pilihan dan kepentingan yang berbeda-beda. Sehingga hal itu dapat menimbulkan ketidakpastian 
Faktor-Faktor Teknis dan Keorganisasian... dalam lingkungan dimana organisasi beroperasi, sehingga organisasi cenderung mengalami kesulitan dalam menetapkan sasaran karena beragamnya stakeholders dengan berbagai kepentingan (Brignall dan Modell, 2000).

Sebagaimana yang telah ditemukan Wang (2002) bahwa tujuan dan sasaran kinerja akan berdampak pada proses perencanaan strategik dan proses managemen dan proses evaluasi kinerja karyawan, De Bruijn (2002) dan Rainey (1999) juga menyimpulkan bahwa tidak adanya konsistensi kebijakan dalam pelaksanaan program dan sistem pengukuran kinerja serta kepentingan politik merupakan sumber ketidakpastian yang memengaruhi tujuan pengukuran kinerja di sektor publik.

Adanya tetidakpastian tersebut menimbulkan keraguan maupun tidak maksimalnya mengadopsi dan mengimplementasikan ukuran kinerja apabila tidak ada aturan tentang konsistensi kebijakan publik, bahkan cenderung untuk saling meniru antara instansi, yang mencerminkan tindakan mimetic isomorphism, yaitu ketidakpastian dan ambiguitas tujuan untuk meningkatkan dampak homogenisasi antar organisasi (DiMaggio dan Powell, 1983). Selain itu, De Bruijn (2002) menegaskan bahwa kesepakatan dalam misi, tujuan dan strategi organisasi harus dicapai dengan melibatkan stakeholders yang beragam, padahal stakeholders memiliki pilihan dan kepentingan yang berbeda-beda, maka hal tersebut dapat menimbulkan ketidakpastian dalam lingkungan di mana organisasi beroperasi, sehingga pemerintah daerah cenderung mengalami kesulitan dalam menetapkan sasaran karena beragamnya stakeholders dengan berbagai kepentingan.

H5a: Tujuan dan sasaran organisasi berpengaruh negatif terhadap pengembangan sistem pengukuran dan evaluasi kinerja anggaran untuk tujuan operasional.

H5b: Tujuan dan sasaran organisasi berpengaruh negatif terhadap pengembangan sistem pengukuran dan evaluasi kinerja anggaran untuk tujuan insentif.

H5c: Tujuan dan sasaran organisasi berpengaruh negatif terhadap pengembangan sistem pengukuran dan evaluasi kinerja anggaran untuk tujuan eksplorasi.

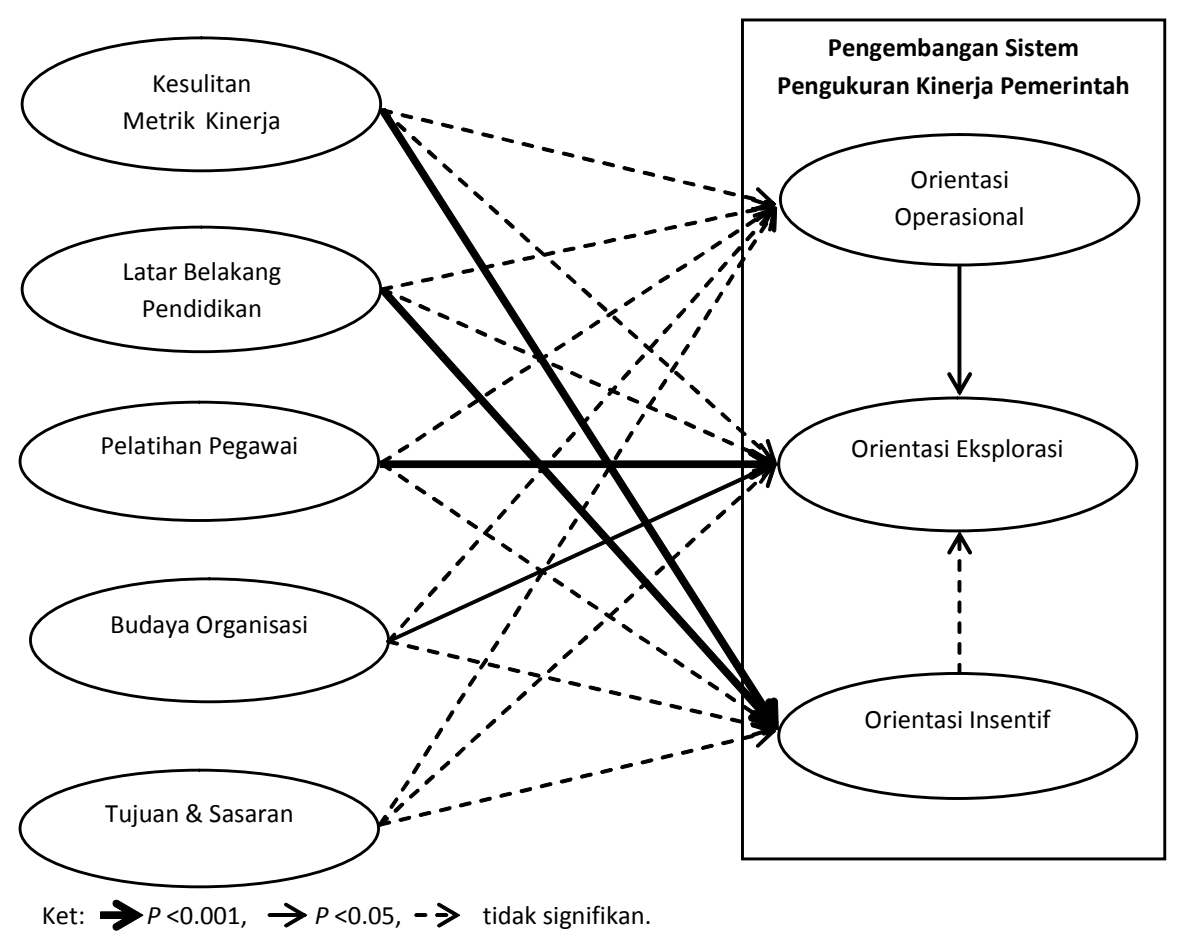

Gambar 1. Model Konseptual 
Pengambilan sampel untuk kebutuhan pengujian pada penelitian ini adalah dengan metoda purposive sampling, yakni dengan memilih sampel dengan kriteria tertentu sesuai dengan kebutuhan analisis masalah pada penelitian ini. Penelitian ini menggunakan sampel pada Kantor Inspektorat Pemerintah Kabupaten Sleman,

Provinsi D.I. Yogyakarta dengan kriteria sebagai pejabat minimal eselon IV dan/ atau sebagai auditor. Kriteria tersebut untuk memastikan bahwa responden adalah pejabat yang terlibat secara langsung dalam penyusunan konsep sistem pengukuran dan evaluasi kinerja anggaran lembaga pemerintah.

\section{Teknik Pengumpulan Data}

Data untuk kebutuhan pengujian secara empiris dan selanjutnya dianalisis diperoleh dengan strategi penelitian eksplanatoris (explanatory). Penelitian ini menggunakan teknik penelitian survei dengan keusioner untuk memperoleh data dari responden. Kuesioner dikembangkan berdasarkan penelitian-penelitian serupa sebelumya. Survei dilaksanakan selama satu bulan dengan pengumpulan secara bertahap setiap sepekan sekali.

\section{Variabel-variabel Penelitian}

\section{Variabel Independen}

Kesulitan Menentukan Indikator Kinerja (DIF) merupakan salah satu faktor teknis yang dihadapi oleh pegawai atau pejabat pemerintahan dalam hal kesulitan mendefinisikan atau menetapkan suatu indikator kinerja untuk menakar atau mengevaluasi ketercapaian suatu program, proyek, ataupun kegiatan. Faktor ini sebelumnya telah diujikan juga oleh Cavaluzzo dan Ittner (2004) serta diujikan dalam konteks Pemerintahan di Indonesia oleh Akbar et al. (2012).

Latar Belakang Pendidikan (EDU) adalah bagian dari kemampuan teknikal para personel yang sudah terlebih dahulu mereka peroleh di lembaga pendidikan yang mereka tempuh sebelumnya. Latar belakang pendidikan dalam penelitian ini dimaksudkan sebagai kemampuan mengembangkan Sistem Pengukuran Kinerja Pemerintah yang telah pegawai peroleh saat menempuh pendidikan.

Pelatihan Pegawai (TRA) merupakan kemampuan teknis yang diperoleh pegawai pemerintah dalam rangka pengembangan Sistem Pengukuran Kinerja melalui program-program pelatihan, workshop, atau seminar. Cavalluzzo dan Ittner (2004), dan Nurkhamid (2008) telah membuktikan bahwa pelatihan yang diberikan kepada pihak manajemen berpengaruh positif terhadap pengembangan Sistem Pengukuran Kinerja Pemerintah.

Budaya Organisasi (CUL) dalam penelitian ini merupakan sistem makna bersama yang dianut oleh pegawai atau pejabat yang menjadi pembeda antara organisasinya dengan organisasi yang lain. Julnes dan Holzer (2001) telah membuktikan bahwa budaya organisasi berpengaruh terhadap implementasi sistem pengukuran kinerja.

Kesamaran Tujuan dan Sasaran Organisasi (GOAL) merupakan ketidakjelasan tujuan dan sasaran program yang ditetapkan pada organisasi sektor publik karena banyaknya silang kepentingan dan permainan politik. De Bruijn (2002) dan Rainey (1999) telah menemukan bahwa tidak adanya konsistensi kebijakan dalam pelaksanaan program dan sistem pengukuran kinerja serta kepentingan politik merupakan sumber ketidakpastian yang memengaruhi tujuan pengukuran kinerja di sektor publik. 
Faktor-Faktor

Teknis dan

Keorganisasian...

456

Tabel 1.

Variabel Penelitian

\section{Variabel Dependen}

Pengembangan Sistem Pengukuran Kinerja Pemerintah dalam penelitian ini merupakan proses perancangan, implementasi, dan evaluasi perangkat penilaian secara periodik efektivitas operasional institusi pemerintah. Penelitian ini kemudian menguji faktor-faktor teknis dan keorganisasian yang diprediksikan memengaruhi pengembangan tersebut untuk tujuan: (i) Operasional (DEVOP); (ii) Insentif (DEVIN); (iii) Eksplorasi (DEVEX). Hal tersebut sesuai dengan apa yang telah dilakukan oleh Speklé dan Verbeeten (2009) yang menjelaskan tujuan pengembangan dan implementasi Sistem Pengukuran Kinerja sektor publik yakni:

1) Tujuan operasional, yaitu didalamnya termasuk perencanaan sampai proses pemantauan;

2) Tujuan penyediaan mekanisme insentif dan penghargaan, dan

3) Tujuan eksplorasi, yaitu untuk double-loop learning, penentuan prioritas dan pengembangan kebijakan.

\begin{tabular}{lccc}
\hline \multicolumn{1}{c}{ Variabel Laten } & Kode & Indikator* & $\begin{array}{c}\text { Jumlah } \\
\text { Indikator }\end{array}$ \\
\hline Pengembangan Operasional & DEVOP & DEVOP1 - DEPOV2 & 2 \\
Pengembangan Insentif & DEVIN & DEVIN1 - DEVIN2 & 2 \\
Pengembangan Eksplorasi & DEVEX & DEVEX2 - DEVEX3 & 2 \\
Kesulitan Indikator & DIF & DIF4 - DIF5 & 2 \\
Latar Belakang Pendidikan & EDU & EDU1 - EDU3 & 3 \\
Pelatihan Pegawai & TRA & TRA1 - TRA5 & 5 \\
Budaya Organisasi & CUL & CUL2 \& CUL4 & 2 \\
Tujuan \& Sasaran Organisasi & GOAL & GOAL1 - GOAL5 & 5 \\
Total & & & 23 \\
\hline
\end{tabular}

*Beberapa indikator dikeluarkan karena tidak memenuhi standar loading score

\section{Metoda Analisis Data}

Penelitian ini memiliki kombinasi variabel atau pemodelan yang cukup kompleks, namun disisi lain juga memiliki jumlah sampel dan tingkat responsi (respon rate) yang rendah karena penelitian ini dilakukan pada instansi pemerintah. Oleh karena pertimbangan tersebut, maka alat analisis yang digunakan untuk pengujian hipotesis dalam penelitian ini adalah Partial Least Square (PLS). Menurut Hartono (2011) PLS merupakan teknik Structural Equation Modeling (SEM) berbasis varian yang secara simultan dapat melakukan pengujian model pengukuran sekaligus pengujian model struktural. Aplikasi statistik yang digunakan untuk mengolah data penelitian ini adalah WrapPLS 3.0 .

\section{HASIL DAN PEMBAHASAN}

Data yang digunakan dalam penelitian ini diperoleh dengan melakukan survei menggunakan kuesioner kepada 50 orang auditor dan pejabat Kantor Inspektorat Kabupaten Sleman. Kuesioner yang berhasil terkumpul sejumlah 44 eksemplar (tingkat responsi sebesar 88\%) dan semuanya memenuhi untuk dapat digunakan dalam penelitian ini. Adapun profil responden berdasarkan kuesioner yang telah dikembalikan terdapat pada Tabel 2 . 


\begin{tabular}{lccc}
\hline & Keterangan & \multicolumn{3}{c}{ Jumlah } \\
\hline Dibagikan & & 50 & $100 \%$ \\
Dikembalikan & & 44 & $88 \%$ \\
Digunakan & & 44 & $88 \%$ \\
& Laki-laki & 15 & $34 \%$ \\
Gender & Perempuan & 29 & $66 \%$ \\
& $<30$ & 4 & $9 \%$ \\
Usia & $30-40$ & 8 & $18 \%$ \\
(tahun) & $41-50$ & 23 & $52 \%$ \\
& $>50$ & 9 & $20 \%$ \\
& $\mathrm{~S} 1$ & 29 & $66 \%$ \\
Pendidikan & $\mathrm{S} 2$ & 8 & $18 \%$ \\
& $\mathrm{~S} 3$ & 0 & $0 \%$ \\
& Lainnya & 7 & $16 \%$ \\
& $<2$ & 2 & $5 \%$ \\
Lama Menjabat & $2-5$ & 10 & $23 \%$ \\
(tahun) & $6-10$ & 14 & $32 \%$ \\
& $11-15$ & 12 & $27 \%$ \\
& $16-20$ & 2 & $5 \%$ \\
& $>20$ & 4 & $9 \%$ \\
\hline
\end{tabular}

ikembalikan

$88 \%$

457

\section{Pengujian Convergent Validity}

Pengujian measurement model dari sebuah analisis PLS dilakukan dengan dua langkah: (i) convergent validity, (ii) discriminant validity. Tahap pertama dari convergent validity adalah reliabilitas item individual dengan menguji loading dari setiap item indikator variabel. Semua indikator dalam penelitian ini masingmasing diatas dari nilai minimal yang persyaratkan yaitu 0.4 (Hair et al., 2006). Tahap berikutnya adalah konsistensi internal dari setiap konstruk dengan menguji composite reliability. Nilai composite reliability akan memadai apabila nilainya lebih dari 0.5. Pada penelitian ini semua konstruk menunjukkan sangat memadai. Literatur lain menyebutkan bahwa instrumen penelitian dikatakan valid apabila composite reliability dan cronbach's alpha lebih besar dari 0.60 dan average variance extracted (AVE) dan loading factor $>0.50$ (Hartono, 2011). Tampak skor AVE tertinggi pada konstruk GOAL $(0,863)$ dan terendah pada konstruk DEVOP $(0,769)$. Hasil pengujian tersebut disajikan dalam Tabel 3.

\begin{tabular}{lccc}
\hline \multicolumn{1}{c}{ Konstruk } & $\begin{array}{c}\text { Composite } \\
\text { reliability }\end{array}$ & $\begin{array}{c}\text { Cronbach's } \\
\boldsymbol{\alpha}^{2}\end{array}$ & AVE \\
\hline Pengembangan Opersional (DEVOP) & 0.866 & 0.691 & 0.764 \\
Pengembangan Insentif (DEVIN) & 0.905 & 0.790 & 0.826 \\
Pengembangan Eksplorasi (DEVEX) & 0.885 & 0.740 & 0.793 \\
Kesulitan Indikator (DIF) & 0.915 & 0.813 & 0.843 \\
Latar Belakang Pendidikan (EDU) & 0.966 & 0.947 & 0.904 \\
Pelatihan Pegawai (TRA) & 0.944 & 0.926 & 0.772 \\
Budaya Organisasi (CUL) & 0.925 & 0.837 & 0.860 \\
Tujuan \& Sasaran Organisasi (GOAL) & 0.969 & 0.960 & 0.863 \\
\hline
\end{tabular}

Tabel 2.

Profil Responden
Tabel 3.

Internal

Consistency and AVE

\section{Pengujian Discriminant Validity}

Uji validitas diskriminan menggunakan parameter skor cross loadings. Pada tabel 4 terlihat bahwa masing-masing indikator pada setiap konstruk di dalam 
Faktor-Faktor Teknis dan Keorganisasian...

Tabel 4.

Correlation Among Latent Variables model pengukuran telah memenuhi syarat validitas diskriminan karena masingmasing indikator di setiap konstruk berbeda dengan indikator pada konstruk lain dan terkumpul pada konstruk tersebut dengan skor $>0,6$.

\begin{tabular}{lrrrrrrrr}
\hline & DEVOP & DEVIN & DEVEX & \multicolumn{1}{c}{ DIF } & EDU & TRA & CUL & GOAL \\
\hline DEVOP & $(0.874)$ & & & & & & & \\
DEVIN & 0.200 & $(0.909)$ & & & & & & \\
DEVEX & 0.540 & 0.158 & $(0.891)$ & & & & & \\
DIF & 0.182 & 0.518 & 0.170 & $(0.918)$ & & & & \\
EDU & -0.135 & -0.333 & 0.041 & 0.004 & $(0.951)$ & & & \\
TRA & 0.375 & 0.056 & 0.481 & -0.047 & 0.035 & $(0.879)$ & & \\
CUL & 0.080 & 0.018 & -0.186 & -0.231 & -0.309 & 0.447 & $(0.927)$ & \\
GOAL & 0.072 & 0.194 & 0.330 & 0.134 & -0.210 & 0.102 & 0.155 & $(0.929)$ \\
\hline
\end{tabular}

Ket: Akar pangkat dua dari average variances extracted (AVE'S) pada kotak diagonal.

\section{Pengevaluasian Model Struktural}

Mengevaluasi model struktural menggunakan nilai $R^{2}$ dari konstruk/variabel dependen. Pada Tabel 5 terlihat nilai $R^{2}$ untuk konstruk DEVOP sebesar 0.467, nilai $R^{2}$ untuk konstruk DEVIN adalah 0.633, sedangkan nilai $R^{2}$ untuk konstruk DEVEX sebesar 0.485. Hasil tersebut berarti bahwa model penelitian yang diajukan pada penelitian ini dapat menjelaskan variabel konstruk Pengembangan Sistem Pengukuran Kinerja untuk Operasional (DEVOP) sebesar 46,70\%, dan sisanya dijelaskan oleh variabel lain di luar model yang diajukan. Begitu pula dengan variabel konstruk Pengembangan Sistem Pengukuran Kinerja untuk tujuan Insentif (DEVIN) sebesar 63.30\% dan sisanya dijelaskan oleh variabel lain di luar model yang diajukan dan variabel konstruk Pengembangan Sistem Pengukuran Kinerja untuk tujuan Eksplorasi (DEVEX) sebesar 48.50\%, dan sisanya dijelaskan oleh variabel lain di luar model yang diajukan.

\begin{tabular}{lc}
\hline \multicolumn{1}{c}{ Konstruk } & $\boldsymbol{R}^{2}$ \\
\hline Pengembangan Opersional (DEVOP) & 0.467 \\
Pengembangan Insentif (DEVIN) & 0.633 \\
Pengembangan Eksplorasi (DEVEX) & 0.485
\end{tabular}

Ket: $0.67=$ substantial, $0.33=$ moderate, $0.19=$ weak $($ Henseler et al., 2009).

\section{Pengujian Hipotesis}

Terdapat 15 (lima belas) hipotesis yang diajukan dalam penelitian ini. Pengujian hipotesis tersebut menggunakan analisis PLS dengan rincian hasilnya ditampilkan pada Tabel 6. 


\begin{tabular}{|c|c|c|c|c|}
\hline Hipotesis & Hubungan & Tanda & Koefisien & P-value \\
\hline \multicolumn{5}{|c|}{ 1. Kesulitan Menentukan Indikator Kinerja } \\
\hline H1a & $\mathrm{DIF} \rightarrow \mathrm{DEVOP}$ & - & -0.218 & 0.316 \\
\hline $\mathrm{H} 1 \mathrm{~b}$ & $\mathrm{DIF} \rightarrow \mathrm{DEVIN}$ & - & $-0.122 * * *$ & 0.005 \\
\hline $\mathrm{H} 1 \mathrm{c}$ & $\mathrm{DIF} \rightarrow \mathrm{DEVEX}$ & - & -0.323 & 0.250 \\
\hline \multicolumn{5}{|c|}{ 2. Latar Belakang Pendidikan } \\
\hline $\mathrm{H} 2 \mathrm{a}$ & $\mathrm{DIF} \rightarrow \mathrm{DEVOP}$ & + & 0.510 & 0.133 \\
\hline $\mathrm{H} 2 \mathrm{~b}$ & $\mathrm{DIF} \rightarrow \mathrm{DEVIN}$ & + & $0.105 * * *$ & 0.001 \\
\hline $\mathrm{H} 2 \mathrm{c}$ & $\mathrm{DIF} \rightarrow \mathrm{DEVEX}$ & + & 0.200 & 0.316 \\
\hline \multicolumn{5}{|c|}{ 3. Pelatihan Pegawai } \\
\hline $\mathrm{H} 3 \mathrm{a}$ & $\mathrm{TRA} \rightarrow \mathrm{DEVOP}$ & + & 0.321 & 0.476 \\
\hline $\mathrm{H} 3 \mathrm{~b}$ & $\mathrm{TRA} \rightarrow \mathrm{DEVIN}$ & + & 0.439 & 0.220 \\
\hline $\mathrm{H} 3 \mathrm{c}$ & TRA $\rightarrow$ DEVEX & + & $0.154 * * *$ & 0.003 \\
\hline \multicolumn{5}{|c|}{ 4. Budaya Organisasi } \\
\hline $\mathrm{H} 4 \mathrm{a}$ & $\mathrm{CUL} \rightarrow \mathrm{DEVOP}$ & + & 0.289 & 0.244 \\
\hline $\mathrm{H} 4 \mathrm{~b}$ & $\mathrm{CUL} \rightarrow \mathrm{DEVIN}$ & + & 0.233 & 0.204 \\
\hline $\mathrm{H} 4 \mathrm{c}$ & $\mathrm{CUL} \rightarrow \mathrm{DEVEX}$ & + & $0.192 *$ & 0.054 \\
\hline \multicolumn{5}{|c|}{ 5. Kesamaran Tujuan dan Sasaran Organisasi } \\
\hline H5a & $\mathrm{GOAL} \rightarrow \mathrm{DEVOP}$ & - & -0.359 & 0.254 \\
\hline $\mathrm{H} 5 \mathrm{~b}$ & $\mathrm{GOAL} \rightarrow \mathrm{DEVIN}$ & - & -0.208 & 0.149 \\
\hline $\mathrm{H} 5 \mathrm{c}$ & GOAL $\rightarrow$ DEVEX & - & -0.141 & 0.203 \\
\hline
\end{tabular}

Ket: $* * * P<0.01, * * P<0.05,{ }^{*} P<0.1$

1. Kesulitan Menentukan Indikator Kinerja yang Memengaruhi Pengembangan Sistem Pengukuran Kinerja Pemerintah (H1a, H1b, H1c)

Pada Tabel 6 terlihat bahwa hubungan antara kesulitan menentukan indikator kinerja dengan pengembangan sistem pengukuran kinerja pemerintah dengan orientasi operasional (H1a) dan orientasi eksplorasi (H1c) memiliki nilai koefisien masing-masing - 0.218 dan - 0.323 dengan $P$-value lebih besar dari nilai signifikansi. Hal tersebut menggambarkan bahwa kedua hipotesis tersebut tidak terdukung. Sedangkan hubungan antara kesulitan menentukan indikator kinerja dengan pengembangan sistem pengukuran kinerja pemerintah dengan orientasi penentuan insentif $(H 1 b)$ dengan koefisien sebesar -0.122 dengan $P$-value $<0.01$, dengan demikian hipotesis tersebut terdukung.

2. Latar Belakang Pendidikan yang Memengaruhi Pengembangan Sistem Pengukuran Kinerja Pemerintah (H2a, H2b, H2c)

Hasil pengujian menunjukkan bahwa hubungan antara latar belakang pendidikan dengan pengembangan sistem pengukuran kinerja pemerintah dengan orientasi operasional (H2a) dan orientasi eksplorasi (H2c) memiliki nilai koefisien masin-masing 0.510 dan 0.200 dengan $P$-value lebih besar dari nilai signifikansi. Hal tersebut menggambarkan bahwa kedua hipotesis tersebut tidak terdukung. Sedangkan hipotesis lainnya menunjukkan hubungan antara latar belakang pendidikan dengan pengembangan sistem pengukuran kinerja pemerintah dengan orientasi penentuan insentif $(H 2 b)$ dengan koefisien sebesar 0.105 dengan $P$-value $<0.01$, dengan demikian hipotesis tersebut terdukung.

3. Pelatihan Pegawai yang Mepengaruhi Pengembangan Sistem Pengukuran Kinerja Pemerintah (H3a, H3b, H3c)

Hubungan antara pelatihan pegawai dengan pengembangan sistem pengukuran kinerja pemerintah dengan orientasi operasional (H3a) dan orientasi insentif ( $H 3 b)$ memiliki nilai koefisien masing-masing 0.321 dan 0.439 dengan

Tabel 6.

Ringkasan Hasil Pengujian Hipotesis 
Faktor-Faktor

Teknis dan

Keorganisasian...
$P$-value lebih besar dari nilai signifikansi. Dengan kata lain, kedua hipotesis tersebut tidak terdukung. Sedangkan hubungan antara pelatihan pegawai dengan pengembangan sistem pengukuran kinerja pemerintah dengan orientasi penentuan eksplorasi (H3c) dengan koefisien sebesar 0.154 dengan $P$-value $<0.01$, yang menunjukkan bahwa hipotesis tersebut terdukung.

4. Budaya Organisasi yang Memengaruhi Pengembangan Sistem Pengukuran Kinerja Pemerintah (H4a, H4b, H4c)

Berdasarkan hasil pengujian, hubungan antara budaya organisasi dengan pengembangan sistem pengukuran kinerja pemerintah dengan orientasi operasional ( $\mathrm{H} 4 \mathrm{a}$ ) dan orientasi insentif $(\mathrm{H} 4 \mathrm{~b})$ memiliki nilai koefisien masingmasing 0.289 dan 0.233 dengan $P$-value lebih besar dari nilai signifikansi. Dengan kata lain, kedua hipotesis tersebut tidak terdukung. Sedangkan hubungan antara budaya organisasi dengan pengembangan sistem pengukuran kinerja pemerintah dengan orientasi eksplorasi $(H 4 c)$ dengan koefisien sebesar 0.192 dengan $P$-value $<0.1$, maka hal tersebut menunjukkan hipotesis ini terdukung.

5. Kesamaran Tujuan dan Sasaran Organisasi yang Memengaruhi Pengembangan Sistem Pengukuran Kinerja Pemerintah (H1a, H1b, H1c)

Hal lain tampak untuk hubungan antara kesamaran tujuan dan sasaran organisasi dengan pengembangan sistem pengukuran kinerja pemerintah, baik dengan orientasi operasional ( $\mathrm{H} 4 \mathrm{a})$, orientasi insentif $(\mathrm{H} 4 \mathrm{~b})$, maupun orientasi eksplorasi terbukti tidak berpengaruh dengan nilai koefisien masingmasing -0.359, -0.208, dan -0.141 dengan masing-masing $P$-value yang lebih besar dari nilai signifikansi. Ketiga hipotesis tersebut tidak terdukung.

\section{SIMPULAN}

Berdasarkan hasil analisis data yang telah dilakukan dengan menggunakan analisis koefisien jalur, diperoleh faktor-faktor atau variabel yang memengaruhi pengembangan sistem pengukuran kinerja di kantor inspektorat pemerintah daerah. Faktor-faktor yang berpengaruh secara signifikan terhadap pengembangan sistem pengukuran kinerja untuk orientasi mekanisme insentif pemerintah daerah adalah kesulitan menentukan indikator kinerja dan latar belakang pendidikan. Selanjutnya, faktor-faktor yang berpengaruh secara signifikan terhadap pengembangan sistem pengukuran kinerja untuk orientasi eksplorasi adalah pelatihan pegawai dan budaya organisasi. Namun, untuk pengembangan sistem pengukuran kinerja pemerintah daerah untuk orientasi operasional, penelitian ini belum berhasil untuk menemukan faktor-faktor apa yang memengaruhinya.

Tidak ditemukannya faktor-faktor yang memengaruhi pengembangan sistem pengukuran kinerja pemerintah daerah tersebut bukannya tidak memiliki dasar. Menurut beberapa responden yang diwawancara oleh peneliti pada saat pengumpulan kuesioner, pengembangan sistem pengukuran kinerja di kantor mereka dengan orientasi eksplorasi telah mereka anggap sebagai tujuan operasional. Sehingga dalam mengembangkan sistem pengukuran kinerja tersebut adalah utuh menjadi sebuah siklus; menjadi tujuan operasional sekaligus menjadi tujuan untuk mengembangkannya lebih lanjut (eksplorasi).

Berdasarkan hasil penelitian ini, tampak bahwa faktor pelatihan pegawai memberikan pengaruh yang sangat penting terhadap pengembangan sistem pengukuran kinerja pemerintah daerah (orientasi eksplorasi), dimana pengembangan dengan orientasi eksplorasi inilah yang akan memberikan nilai tambah pada sistem pengukuran kinerja dari waktu ke waktu. Hal tersebut juga mendukung hasil penelitian yang dilakukan oleh Cavalluzzo dan Ittner (2004), serta Nurkhamid (2008) yang telah membuktikan bahwa pelatihan yang diberikan kepada pihak manajemen berpengaruh positif terhadap pengembangan sistem 
pengukuran, akuntabilitas, dan penggunaan informasi kinerja yang dihasilkan oleh implementasi sistem pengukuran kinerja, sehingga hal tersebut memperlihatkan bahwa tindakan-tindakan yang dilakukan oleh personel di lingkungan pemerintah daerah didorong oleh kekuatan normative isomorphism.

Faktor latar belakang pendidikan yang terbukti berpengaruh positif terhadap pengembangan sistem pengukuran kinerja pemerintah daerah untuk orientasi insentif menunjukkan bahwa para personel hanya mendapatkan keterampilan untuk dapat membuat mekanisme insentif (reward). Hal tersebut merupakan salah satu dari tujuan sistem pengukuran kinerja dikembangkan untuk memberikan stimulasi pada para personel/pegawai pemerintah agar terus meningkatkan kinerja mereka.

Di sisi lain, faktor penghambat (negatif) yang terbukti berpengaruh dari pengembangan sistem pengukuran kinerja pemerintah daerah adalah kesulitan dalam menentukan indikator kinerja. Hal tersebut mendukung penelitian terdahulu oleh Cavalluzzo dan Ittner, 2004 serta Akbar et al., 2012 yang telah membuktikan bahwa kesulitan menentukan ukuran kinerja berpengaruh negatif terhadap pengembangan sistem pengukuran kinerja, akuntabilitas kinerja dan penggunaan informasi kinerja yang dihasilkan oleh implementasi sistem pengukuran kinerja.

Hasil penelitian ini dapat dijadikan bahan masukan bagi pemerintah daerah sebagai implikasinya. Secara khusus, temuan penelitian ini dapat menjadi panduan dalam hal pengembangan sistem pengukuran kinerja untuk menilai sampai sejauh mana tingkat keberhasilan capaian organisasi dalam melayani masyarakat.

Penelitian ini memiliki banyak keterbatasan. Salah satu diantaranya, penelitian ini hanya dilakukan dalam sebuah institusi pelaksana tugas pemerintah daerah saja, sehingga kurang mampu mengeneralisasi praktik-praktik pengukuran kinerja pemerintah daerah di Indonesia. Sebagai saran, peneliti berikutnya dapat melakukannya dengan objek penelitian yang lebih luas dan mencari faktorfaktor lain yang dapat menangkap fenomena isomorphisma dalam mempengaruhi penggunaan sistem pengukuran kinerja pemerintah. Selanjutnya, penggunaan mixed method sangat disarankan bagi penelitian berikutnya, karena dengan menggunakan teknik ini, maka hasil yang diperoleh dapat digali lebih dalam dan dapat melihat dari sudut pandang yang beragam dan kaya dibandingkan apabila hanya menggunakan satu analisis saja.

\section{DAFTAR PUSTAKA}

Abernethy, M. A., \& Brownell, P. (1999). The role of budgets in organizations facing strategic change: an exploratory study. Accounting, organizations and society, 24(3), 189-204.

Akbar, R., Pilcher, R., \& Perrin, B. (2012). Performance measurement in Indonesia: the case of local government. Pacific Accounting Review, 24(3), 262-291.

Bodnar, G. H., \& Hopwood, W. S. (2000). Sistem Informasi Akuntansi. Buku Satu, Salemba Empat, Jakarta.

Brignall, S., \& Modell, S. (2000). An institutional perspective on performance measurement and management in the 'new public sector'. Management Accounting Research, 11(3), 281-306.

Cavalluzzo, K. S., \& Ittner, C. D. (2004). Implementing performance measurement innovations: evidence from government. Accounting, Organizations and $\mathrm{So}^{-}$ ciety, 29(3), 243-267.

Chen, L. T., Chen, C. W., \& Chen, C. Y. (2010). Are educational background and gender moderator variables for leadership, satisfaction and organizational commitment. African Journal of Business Management, 4(2), 248-261.

Creswell, J. W. (2012). Research design: Pendekatan Kualitatif, Kuantitatif, dan Mixed Edisi Ketiga. Yogyakarta: Pustaka Pelajar. 
Faktor-Faktor Teknis dan Keorganisasian...
Dacin, M. T., Goodstein, J., \& Scott, W. R. (2002). Institutional theory and institutional change: Introduction to the special research forum. Academy of management journal, 45(1), 45-56.

De Bruijn, H. (2002). Performance measurement in the public sector: strategies to cope with the risks of performance measurement. International Journal of Public Sector Management, 15(7), 578-594.

DiMaggio, Paul J., and Walter W.Powell. 1983. The Iron Cage Revisited: Institutional Isomorphism and Collective Rationality in Organizational Fields. American Sociological Review 48: 147-160

Fontanella, A. (2012). Analisis Pengaruh Latar Belakang Pendidikan dan Pengetahuan Akuntansi Pengguna Terhadap Pemanfaatan Laporan Keuangan Pemerintah Daerah. Jurnal Akuntansi \& Manajemen, 5(2), 22-30.

Hair Jr, J. F., Black, W. C., Babin, B. J., \& Anderson, R. E., (2009). Multivariate data analysis $7^{\text {th }}$ Edition. Pearson Prentice Hall.

Hambrick, D. C., \& Mason, P. A. (1984). Upper echelons: The organization as a reflection of its top managers. Academy of management review, 9(2), 193-206.

Hansen, S. C., \& Stede, W. A. (2004). Multiple facets of budgeting: an exploratory analysis. Management accounting research, 15(4), 415-439.

Hartono, Jogiyanto. (2011). Konsep dan Aplikasi Structural Equation Modeling Berbasiskan Varian dalam Penelitian Bisnis. Yogyakarta: STIM YKPN.

Henri, J.F. (2006). Organizational Culture and Performance Measurement Systems. Accounting, Organizations and Society, 31: 77-103

Hitt, M. A., \& Tyler, B. B. (1991). Strategic decision models: Integrating different perspectives. Strategic Management Journal, 12(5), 327-351.

Julnes, P. de Lancer and Holzer, M. (2001). Promoting the Utilization of Performance Measures in Public Organization: an Emprirical Tudy of Factors Affecting Adoption and Implementation. Public Administration Review 61(6), P. 693-708

Kementerian Keuangan Republik Indonesia, (2011). Peraturan Menteri Keuangan (PMK) Republik Indonesia Nomor 249 Tahun 2011 tentang Pengukuran dan Evaluasi Kinerja atas Pelaksanaan Rencana Kerja Anggaran Kementerian dan Lembaga $(R K A-K / L)$. Jakarta.

Lembaga Administrasi Negara, (2003). Keputusan Kepala Lembaga Administrasi Negara (LAN) Nomor 239/IX/6/8/2003 tentang Pedoman Penyusunan Pelaporan Akuntabilitas Kinerja Instansi Pemerintah. Jakarta.

March, J. G., \& Olsen, J. P. (1984). The new institutionalism: organizational factors in political life. The American Political Science Review, 734-749.

Mardiasmo. (2009). Akuntansi Sektor Publik. Andi, Yogyakarta

Mulyadi, (2001), Balanced Scorecard: Alat Manajemen Kontemporer untuk Pelipatgandaan Kinerja Keuangan Perusahaan. Salemba Empat, Jakarta.

Nasir, M. (2010). Perubahan Sistem Penganggaran di Indonesia dan Dampaknya Pada Kinerja. Pidato Pengukuhan Guru Besar Universitas Diponegoro. Semarang.

Nurkhamid Muh. (2008). Implementasi Inovasi Sistem Pengukuran Kinerja Instansi Pemerintah. Jurnal Akuntansi Pemerintah Vol. 3, No. 1, Oktober. $45-76$

Panozzo F. (2000). Management by Decree. Paradoxes in the Reform of the Italian Public Sector. Scandinavian Journal of Management 16. 357-373

Parlinda, V., \& Wahyuddin, M. (2004). Pengaruh Kepemimpinan, Motivasi, Pelatihan, Dan Lingkungan Kerja Terhadap Kinerja Karyawan Pada Perusahaan Daerah Air Minum Kota Surakarta. Dayasaing: Jurnal Ekonomi \& Manajemen Bisnis 4(2), 86-101. 
Rainey, Hal G. (1999). Using Comparisons of Public and Private Organization to Assess Innovative Attitudes Among Members of Organizations. Public Productivity and Management Review Vol.23,No.2, Sage Publications,Inc, hal.130147

Republik Indonesia, (1999). Instruksi Presiden Nomor 7 Tahun 1999 tentang Akuntabilitas Kinerja Instansi Pemerintah. Jakarta.

Sihaloho, F. Laurensius dan Halim, A. (2005). Pengaruh Faktor-Faktor Rasional, Politik dan Kultur Organisasi Terhadap Pemanfaatan Informasi Kinerja Instansi Pemerintah Daerah. Simposium Nasional Akuntansi VIII Solo, 1516 September. Hal. 774-790

Speklé Roland F. and Verbeeten Frank H.M. (2009). The Use of Performance Measurement Systems in The Public Sector: Effects on Performance. Nyenrode Research \& Innovation Institute (NRI) Research Paper no. 09-08. April

Tjiptoherijanto, Prijono. (2007). Civil Service Reform in Indonesia. International Public Management Review 8 (2): 31-44.

The Urban Institute. (2002). How and Why Nonprofits Use Outcome Information. The Urban Institute, Washington, D.C.

Tolbert, Pamela S. and Zucker Lynne G. (1983). Institutional Sources of Change In The Formal Structure of Organizations: The Diffusion of Civil Service Reforms. 1880-1 935." Administrative Science Quarterly 23: 22-39

Van Helden, G. J. (2005). Researching public sector transformation: the role of management accounting. Financial Accountability \& Management, 21(1), 99133.

Verbeeten, F. H. (2008). Performance management practices in public sector organizations: impact on performance. Accounting, Auditing \& Accountability Journal, 21(3), 427-454.

Wang, Xiahou. (2002). Assesing Performance Measurement Impact: A study of US Local Government. Public Performance and Management Review. Vol. 26: 2643

Wholey, J. S. (1999). Performance-based management: Responding to the challenges. Public Productivity \& Management Review, 288-307.

Wijaya, C., Anthonius, H., \& Akbar, R. (2013). The Influence of Information, Organizational Objectives and Targets, and External Pressure Towards The Adoption of Performance Measurement System in Public Sector. Journal of Indonesian Economy \& Business, 28(1).

Zucker, Lynne G. (1977). The Role Of Institutionalization In Cultural Persistence. American Sociological Review 42: 726-743

Zucker, Lynne G. (1987). Institutional Theories Of Organizations. Annual Review of Sociology 13: 443-464. Palo Alto, CA: Annual Reviews 
